\title{
Pengembangan usaha pada Badan Usaha Milik Gampong (BUMG) dalam pembuatan batu bata tanpa pembakaran di Gampong Seuneubok Baroh Kecamatan Darul Aman Kabupaten Aceh Timur
}

\author{
Faiz Isma*, Irwansyah, dan Heri Irawan \\ Universitas Samudera Meurandeh Langsa Aceh \\ * faizisma.ts@unsam.ac.id
}

\begin{abstract}
Abstrak. Kegiatan Program Kemitraan Masyarakat (PKM) yang diusulkan akan memberikan solusi terhadap kendala BUMG dalam pengembangan unit usaha baru dengan melakukan inovasi batu bata tanpa pembakaran yang ramah lingkungan, efektif dan efisien. Mitra dalam hal ini BUMG gampong Seneubok Baroh memiliki sumber daya alam yang melimpah salah satunya ketersediaan tanah liat sebagai bahan dasar dalam membuat batu bata tanpa bakar.

Permasalahan yang dihadapi mitra saat ini adalah BUMG tidak berjalan efektif, minimnya pengetahuan dari pengelola BUMG dalam memanfaatkan potensi SDA dalam pengembangan usaha baru yang mampu meningkatkan kesejahteraan gampong. Metode kegiatan pengabdian yang dipakai antara lain pelatihan dan pendampingan dalam pembuatan usaha baru BUMG yaitu batu bata tanpa di bakar, penyediaan dan pelatihan alat pencetak batu bata, pembuatan dan pelatihan e-commerce berbasis website dan pelatihan aplikasi keuangan. Tingkat ketercapaian dapat dilihat dari sisi perubahan sikap, sosial budaya, dan ekonomi masyarakat sasaran dengan adanya unit usaha baru untuk BUMG yang selama ini belum ada unit usaha, melatih mitra untuk operasional usaha batu bata tanpa dibakar, melatih neraca keuangan usaha dan melatih admin BUMG untuk mengelola website untuk promosi usaha batu bata.
\end{abstract}

Kata kunci: BUMG, e-commerce, aplikasi keuangan, pembuatan batu bata tanpa pembakaran

Abstract. The proposed Program Kemitraan Masyarakat (PKM) will provide solutions to the constraints of BUMG in developing new business units by innovating environmentally friendly and effective bricks without burning. Partners in this case the village BUMG Seneubok Baroh have abundant natural resources, one of which is the availability of clay as a basic ingredient in making bricks without burning. The problem faced by partners now is that BUMG is not running effectively, the lack of knowledge from BUMG managers in utilizing the potential of SDA in developing new businesses that are able to improve the welfare of the village. the methods of service activities used include training and mentoring in the making of new BUMG businesses, ie bricks without burning, provision and training of brick molding tools, website-based e-commerce creation and training and financial application training. The level of achievement can be seen in terms of attitudes, socio-cultural, and economic changes in the target community with the existence of a new business unit for BUMG which has not yet had a business unit, training partners for brick business operations without being burned, training business financial balance and training BUMG admins to managing websites for the promotion of brick businesses.

Keywords: BUMG, e-commerce, financial aplication, brick business without being burned

To cite this article: Isma, F., Irwansyah, \& H. Irawan. 2019. Pengembangan usaha pada Badan Usaha Milik Gampong (BUMG) dalam pembuatan batu bata tanpa pembakaran di Gampong Seuneubok Baroh Kecamatan Darul Aman Kabupaten Aceh Timur. Unri Conference Series: Community Engagement 1: 31-38. https://doi.org/10.31258/unricsce.1.31-38

(C) 2019 Authors

Peer-review under responsibility of the organizing committee of Seminar Nasional Pemberdayaan Masyarakat 2019 


\section{PENDAHULUAN}

Gampong Seuneubok Baroh adalah Gampong yang terletak di kecamatan Darul Aman Kabupaten Aceh Timur. Luas wilayah gampong seunebok baroh adalah $488,25 \mathrm{Ha}$, secara fisik sebagian besar wilayahnya adalah lahan pekarangan dan tanah sawah. Akan tetapi sebagian besar penduduknya bermata pencarian sebagai nelayan dan ada sebagian sebagai petani garam. Dengan kondisi tersebut pemerintah Gampong Seuneubok Aceh berinisiatif menggunakan dana desa untuk pengembangan Badan Usaha Milik Gampong (BUMG).

Awalnya dana desa yang digunakan BUMG ini memulai usaha agen penampungan ikan, peternakan ayam dan itik. Akan tetapi semua usaha yang di rintis tidak ada yang berkembang bahkan masuk kategori bangkrut. Banyak hal yang menjadi faktor kebangkrutan usaha tersebut diantaranya usaha yang di rintis kurang menjanjikan, kurang nya inovasi dari usaha yang dirintis, dan minimnya pengetahuan managemen usaha yang baik. Sampai saat ini BUMG kesulitan untuk menentukan jenis usaha baru yang akan di rintis lagi. Padahal Sumber Daya Alam di desa ini cukup melimpah salah satunya tanah liat yang bisa dijadikan sebagai bahan baku usaha batu bata.

Berdasarkan kesepakatan dengan mitra yaitu perangkat gampong dan pengelola BUMG tertarik terhadap tawaran mitra tentang pembentukan unit usaha pembuatan bata tanpa bakar melalui BUMG Seuneubok Baro dengan memeberikan pelatihan dan pendampingan operasional usaha batu bata, pelatihan keuangan usaha, dan pelatihan admin untjuk kelola website e- commerce

\section{Masalah}

Permasalahan Prioritas yang dihadapi Mitra adalah:

a. Kurangnya pengetahuan mitra untuk menentukan jenis usaha baru yang potensial

b. BUMG tidak berjalan efektif, minimnya pengetahuan dari pengelola BUMG dalam memanfaatkan potensi

SDA dalam pengembangan usaha baru yang mampu meningkatkan kesejahteraan gampong,

c. masih kurang pengetahuan tentang manajemen pengelolaan suatu usaha

d. Keterbatasan mitra dalam melakukan promosi hasil produksi media sosial melalui internet

Permasalahan prioritas yang dihadapi mitra dan hasil dari kesepakatan antara pengusul Program Kemitraan Masyarakat (PKM) dengan Mitra di peroleh solusi sebagai berikut:

a. Pelatihan dan pendampingan dalam pembuatan usaha baru BUMG yaitu batu bata tanpa di bakar

b. Penyediaan dan pelatihan alat pencetak batu bata

c. Pelatihan aplikasi komputer dalam mengatur transaksi keuangan aliran kas (Cash Flow)

d. Pembuatan E-Commerce berbasis website dan pendampingan adminnya

Dasar dari pelaksanaan PKM adalah pengaplikasikan hasil riset penelitian Batu bata tanpa pembakaran dari limbah industry pertanian dan material alam. Laporan penelitian dosen Muda LPPM-PM UNSAM (Irwansyah, dkk. 2018) dari tim pengusul terhadap masyarakat.

\section{METODE PENERAPAN}

1. Tantangan yang dihadapi dalam pengabdian ini adalah warga masih belum begitu mengenal tentang usaha batu bata, mereka masih terbiasa dengan pekerjaan melaut sebagai mata pencaharian utama. Oleh karena itu tim kami berusaha secara maksimal dalam mengenalkan usaha ini mulai dari produksi batu batanya, bagaimana pemasarannya dan pengeloaan keuangannya.

2. Metode yang diterapakan dalam pelaksanaan kegiatan Pengabdian Kepada Masyarakat (PKM) ini adalah pelatihan dan pendampingan kepada masyarakat gampong dalam meningkatkan pendapatan BUMG Seuneubok Baroh yang diharapkan dapat berkontribusi dalam mengatasi pengangguran masyarakat gampong tersebut.

3. Lokasi PKM dilakukan di Gampong seunabok Baroh kecamatan Darul Aman Kabupaten Aceh Timur lebih tepatnya di Kantor Geuchik untuk pelatihan e commerce dan disebidang tanah yang dijadikan tempat untuk produksi batu bata yang di kelola BUMG setempat

4. Waktu Pelaksanaan: maret- Juli 2019 dengan rincian pelaksanaan
a. perancangan dan pembuatan alat produksi bata dari bulan maret sampai mei 2019.
b. Sosialisasi PKM awal mei 2019
c. Penyerahan alat bata tanpa bakar Juni 2019
d. Pelatihan dan pendampingan produksi batu bata Juni 2019
e. Pelatihan e commerce 6 Juli 2019
f. Pelatihan pengelolaan keuangan 12 Juli 2019 


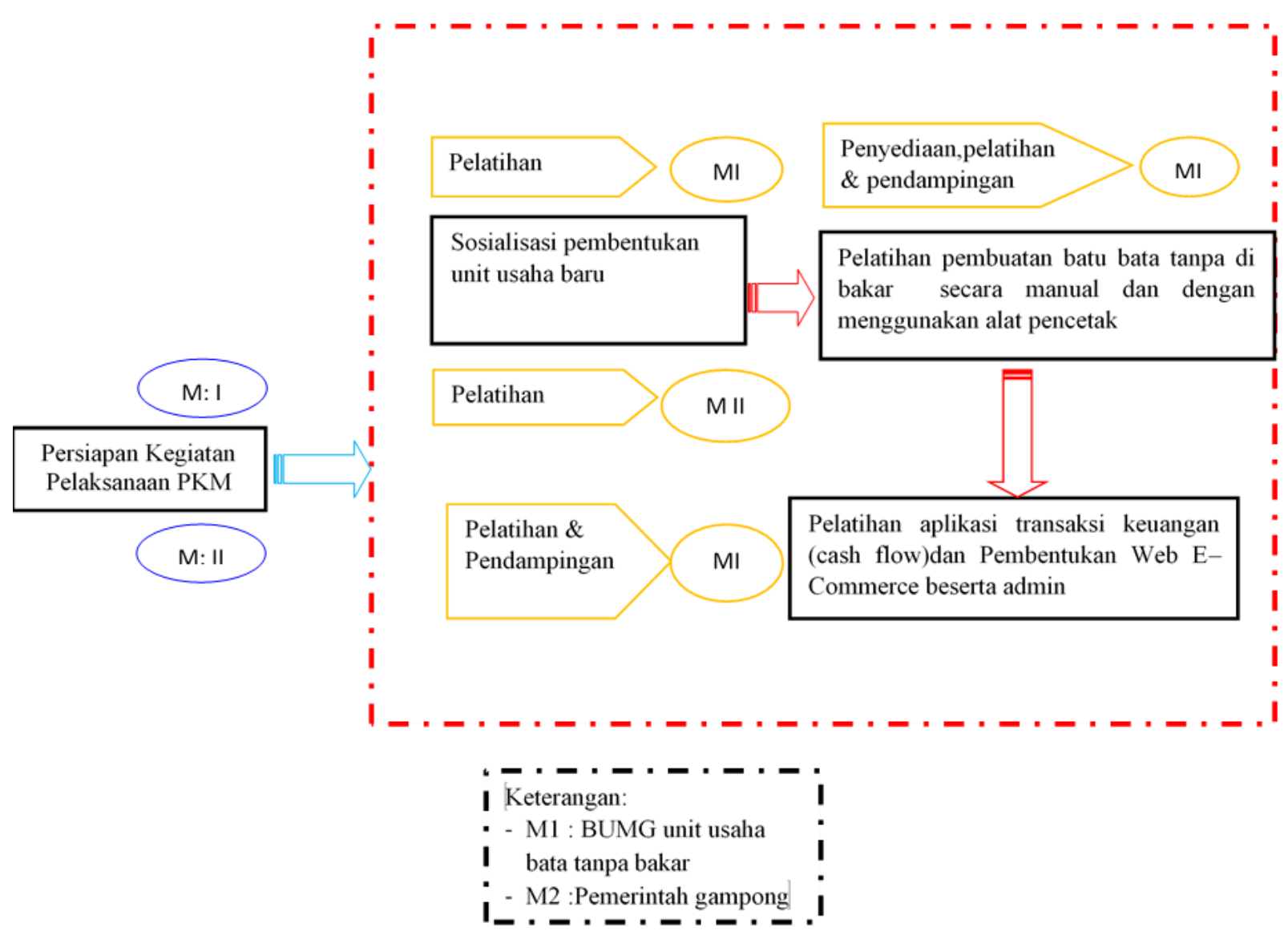

Gambar 1. Bagan Alir Metode Pelaksanaan

\section{HASIL DAN KETERCAPAIAN SASARAN}

1. Dimensi dan spesifikasi (untuk barang/peralatan) yang menjadi luaran atau fokus utama kegiatan PKM kami antara lain:

a. Alat produksi batu bata
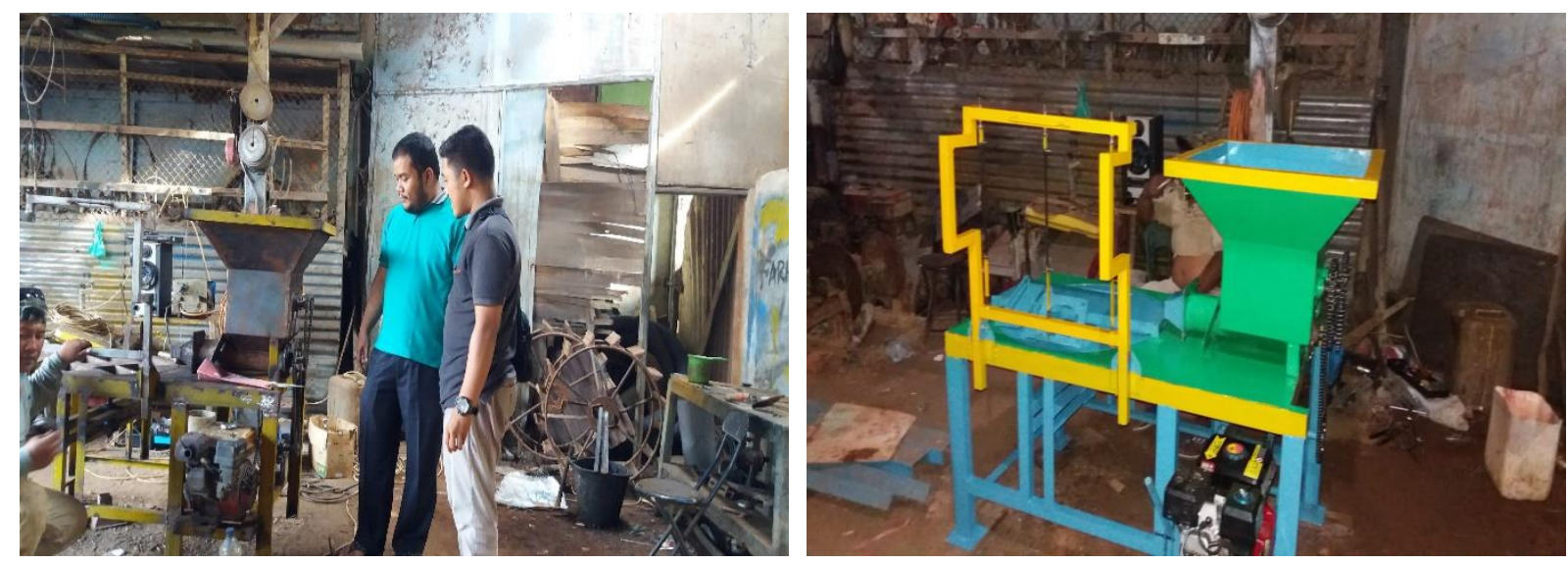

Gambar 2. alat pencampur dan pencetak batu bata

Spesifikasi dan dimensi alat:

1. Alat mixer/pencampur : $(70 \times 70 \times 80) \mathrm{cm}$

2. Alat pencetak $:(80 \times 150 \times 80) \mathrm{cm}$

3. Mesin penggerak : $(34 \times 26 \times 32) \mathrm{cm}$ dengan daya $6,5 \mathrm{HP}$ dan kapasitas bahan bakar 3,5 liter bensin 
b. Produk bata tanpa bakar dengan dimensi $(220 \times 110 \times 55) \mathrm{mm}$

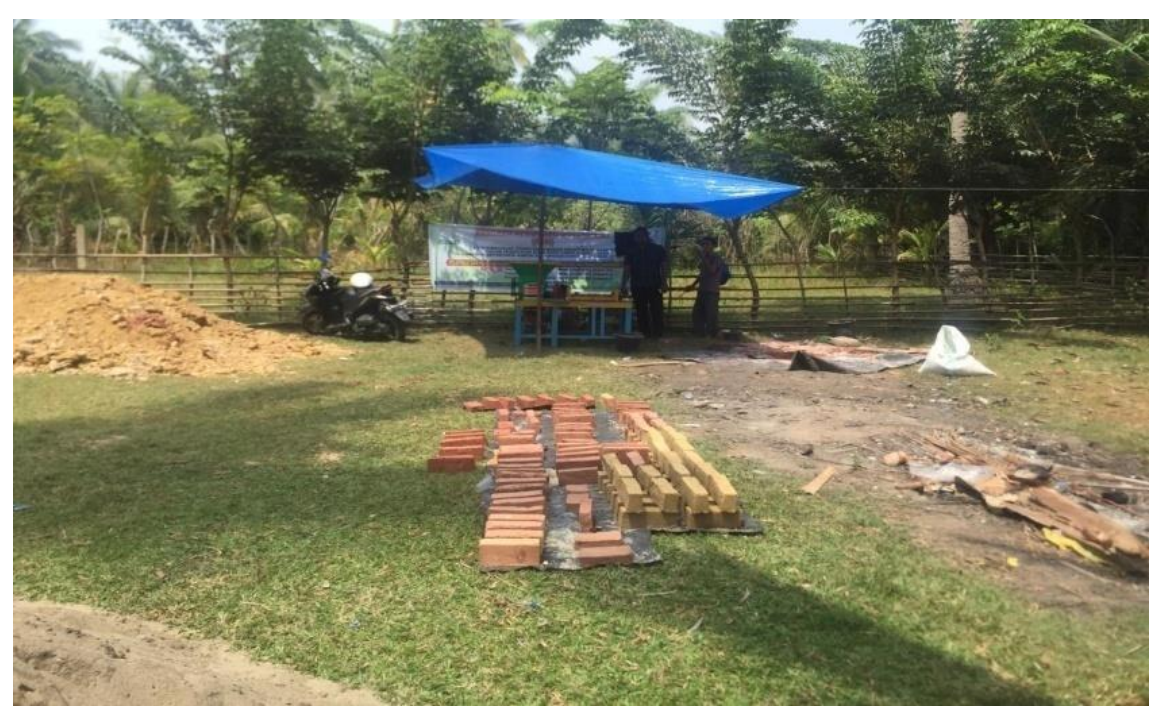

Gambar 3. batu bata tanpa pembakaran setelah di cetak

c. e- commerce berbasis website dengan alamat http://seuneubokbaroh.com/

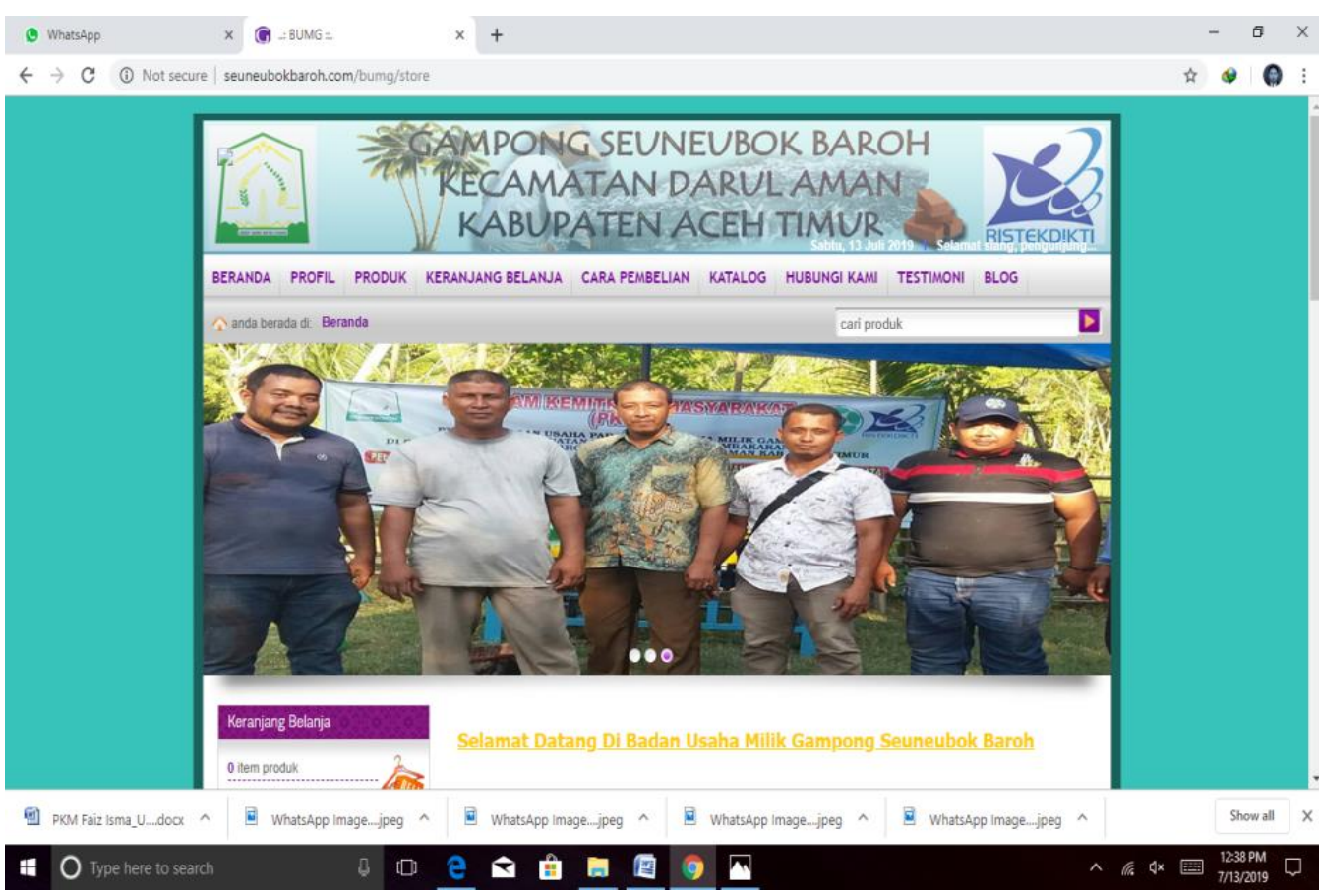

Gambar 4. Tampilan e-commerce BUMG 
d. Aplikasi pengelola keuangan

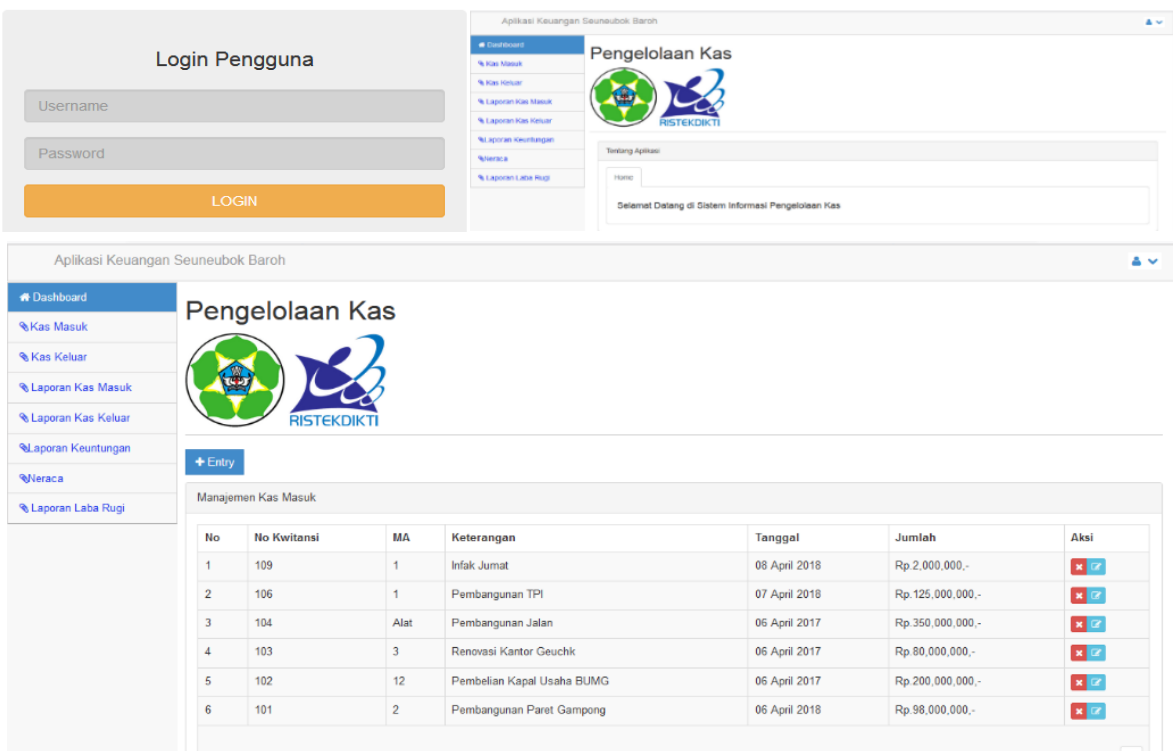

Gambar 5. Tampilan aplikasi keuangan BUMG Seuneubok Baroh

\section{Metode dan Evaluasi Kegiatan Pengabdian}

Hasil pengabdian ini dapat diukur secara kualitatif. Tingkat ketercapaian dapat dilihat dari sisi perubahan sikap, sosial budaya, dan ekonomi masyarakat sasaran.

1. Dari sisi sikap terlihat dari perubahan masyarakat yaitu kemandirian. Terutama terlihat saat kegiatan ada beberapa ibu rumah tangga yang terlibat pelatihan. Meraka di proyeksikan jadi pekerja di BUMG ini. Selain itu kemandirian juga terlihat dari operator desa saat pelatihan e commerce dan aplikasi keuangan. Dengan antusiasnya mendengarkan dan bertanya saat pelatihan

2. Dari sisi sosial budaya dengan adanya kegiatan pengabdian ini terjadi perubahan sosial dari rata-rata seorang nelayan bahkan tidak ada pekerjaan menjadi pekerja BUMG.

3. Sedangkan dari sisi ekonomi sangat jelas dengan meningkatnya kegiatan di BUMG khsususnya unit batu bata bisa meningkatkan perekonomian masyarakat.

\section{Dokumentasi kegiatan pelaksanaan}

a. Diskusi dengan geucik, perangkat desa dan pengurus BUMG

Kegiatan ini dilakukan saat awal sebelum pelaksanaan dimulai dengan diskusi dengan geuchik gampong seuneubok Baroh dilanjutkan dengan ramah amah dengan pengurus BUMG dan perangkat desa
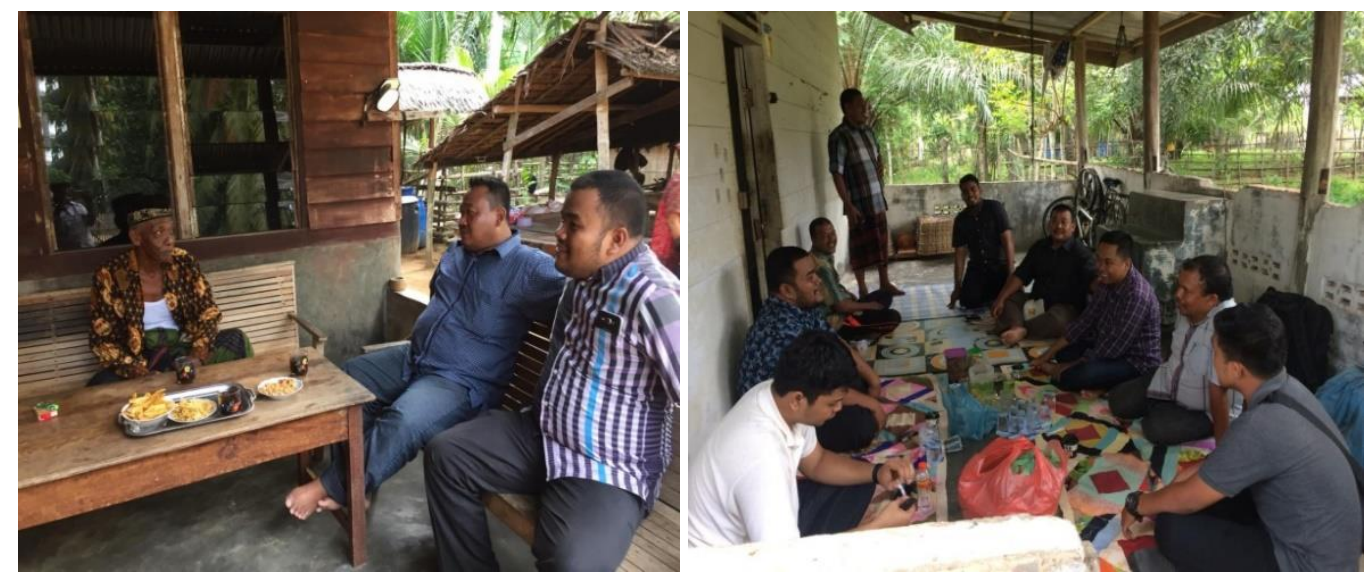

Gambar 6. Rembuk bersama geucik dan pengurus BUMG

b. Penyerahan alat produksi batu bata

Penyerahan alat yang dilakukan dilokasi yang dijadikan untuk unit usaha batu bata yang diwakili oleh sekertaris desa dan dihairi pengurus BUMG dan pemuda setempat. 


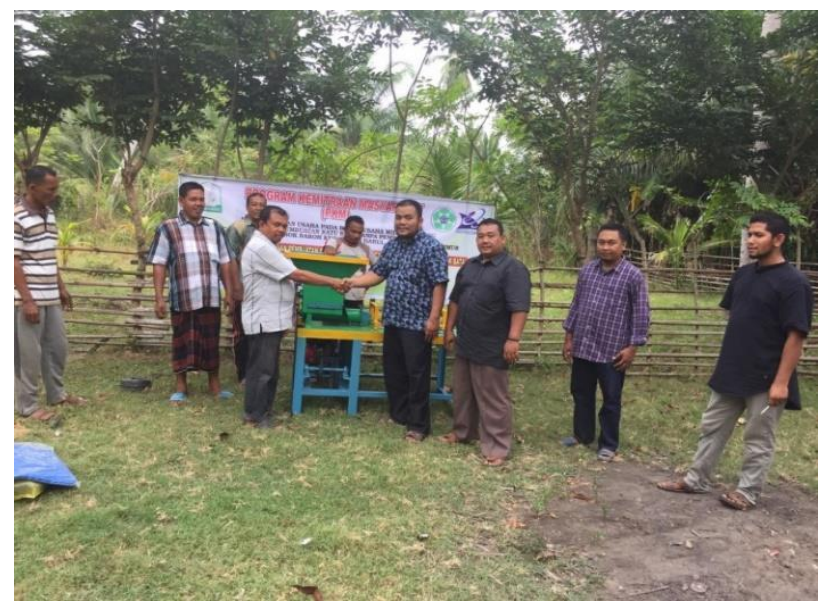

Gambar 7. Serah terima alat yang di wakili sekertaris desa

c. Pelatihan dan penampingan produksi bata

Setelah alat diberikan dilanjutkan kegiatan produksi batu bata yang dimulai dengan penjelasan teknis oleh ketua PKM dan dilanjutkan tahap pencampuran dan pencetakan batu bata. Antusias warga terlihat dari banyaknyapeserta yang hadir sampai ibu-ibu dan anak-anak dating.

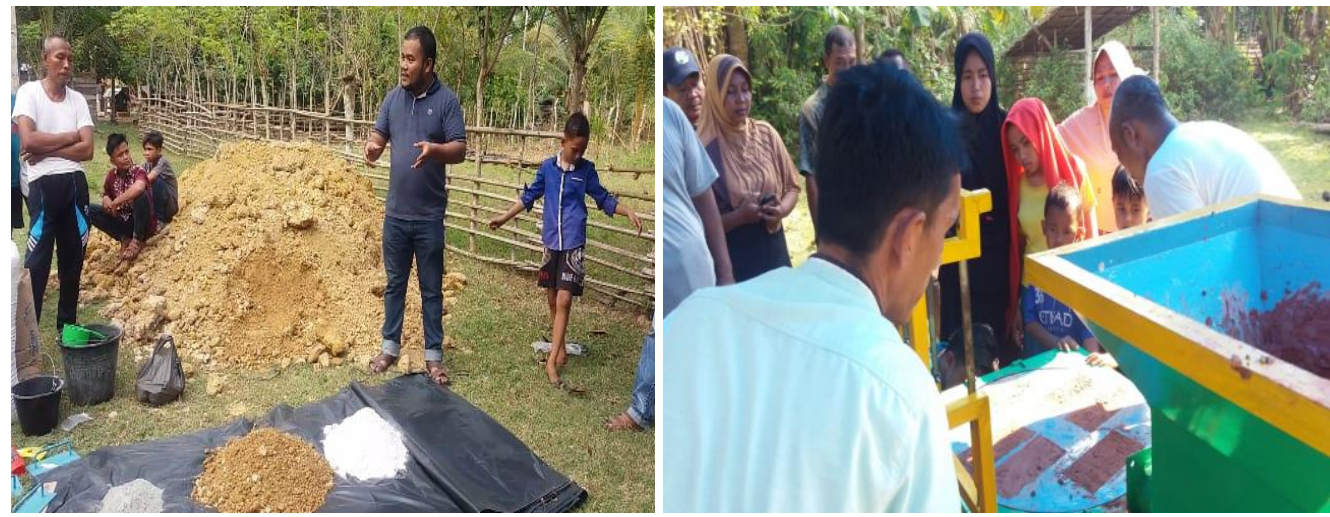

Gambar 8. Pelatihan dan pendampingan pembuatan bata tanpa pembakaran

d. Pelatihan dan pendampingan e commerce dan aplikasi keuangan

Pelatihan e commerce an aplikasi keuangan dilakukan di kantor geuchik seunabok baroh dimana dihadiri perangkat desa dan pengurus BUMG. Dalam hal ini tim pengabdi melatih admin perwakilan dari gampong untuk mengelola website dan aplikasi keuangan. Ditunjuk operator dan bendahara desa yang dijadikan admin.
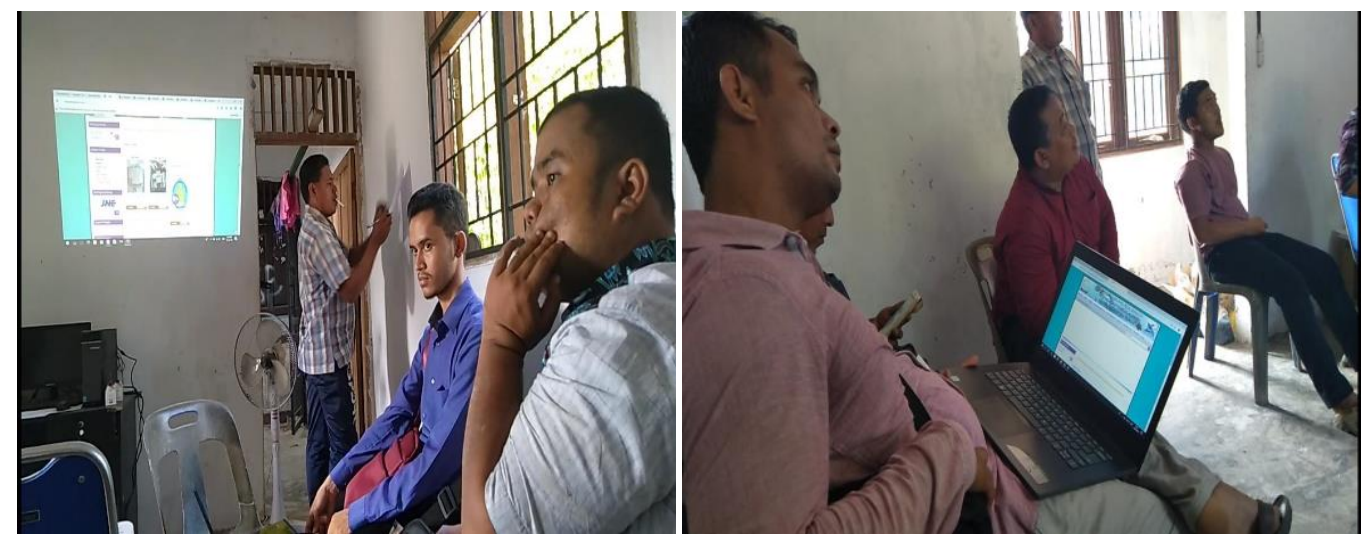

Gambar 9. pelatihan dan pendampingan pengolahan website e-commerse dan aplikasi keuangan di kantor kheuchik Seuneubok Baroh 


\section{Keunggulan dan Kelemahan Luaran}

a. Alat produksi batu bata

- Keunggulan: mempunyai alat mixer yang berfungsi untuk melakukan pengadukan secara sempurna agar campuran jadi homogen, dalam waktu 15 menit mampu mencetak bata sebanyak 6 buah, alat ini bisa dikombinasikan dengan alat cetak manual untuk meningkatkan kapasitas produksinya.

- Kelemahan: Alat ini hanya belum mampu memproduksi batu bata dalam skala besar sehingga perlu ditambahkan alat cetak secara manual

b. Batu bata tanpa pembakaran

- Keunggulan: secara fisik sama dengan batu bata dengan pembakaran tetapi proses pembuatanya yang lebih cepat dari pada bata pembakaran hanya butuh waktu 5 hari bisa langsung dipasarkan, secara uji tekan bata masuk kriteria SNI

- Kelemahan: Belum begitu dikenal kalayak masyarakat awam maka perlu ditingkatkan pemasaranya.

c. Pembentukan e-commerce BUMG Seuneubok Barok

- Keunggulan: e-commerce yang didesain sangat sederhana sehingga mudah di mengerti baik admin dari masyarakat maupun calon konsumen, e commerce ini bisa dikembangkan menjadi website desa/gampong yang saat ini belum mempunyai website desa

- Kelemahan: desain sangat sederhana karena warga gampong masih minim pengetahuan tentang penggunaan computer sehingga pengabdi mendesain secara sederhana

d. Aplikasi keuangan

- Keunggulan: mampu menyajikan informasi keuangan kepada pihak internal dan eksternal dan sebagai dasar membuat keputusan khususnya dalam unit usaha dan penyaluran dana desa

- Kelemahan: aplikasi ini hanya mencakup kas keluar dan masuk saja

\section{Tingkat Kesulitan Pelaksanaan Kegiatan PKM antara lain:}

- Tingkat pendidikan warga gampong setempat yang rendah sehingga sangat kesulitan saat pelatihan e commerce dan aplikasi keuangan

- Kesulitan dalam komunikasi dengan warga dikarenakan banyak menggunakan bahasa daerah

\section{KESIMPULAN}

Dari hasil kegiatan yang telah dilakukan dapat diambil kesimpulan antara lain. Tingkat ketercapaian dapat dilihat dari sisi perubahan sikap, sosial budaya, dan ekonomi masyarakat sasaran Hal ini menggambarkan semua kegiatan yang dilakukan semua dilaksanakan sesuai yang direncanakan dan berdampak positif terhadap masyarakat gampong seuneubok Baroh sebagai mitra. Hal ini tergambar dari antusias warga saat pelaksanaan kegiatan dan khususnya untuk pemerintah gampong merasa sangat terbantu dengan adanya aplikasi ecommerce serta bisa dijadikan website gampong dan aplikasi keuangan bisa dimanfaatkan untuk mengelola dana desa dan usaha BUMG. Untuk BUMG itu sendiri kegiatan ini menjadi dasar pembentukan usaha baru untuk pengembangan dana desa dengan kegiatan yang produktif. Saran untuk kegiatan pengabdian berikutnya adalah kegiatan yang bisa mengembangkan potensi dari desa ini khususnya di bidang peikanan khususnya dalam permasalahan penyediaan pakan pada tambak warga yang saat ini masih diperoleh dari pabrikan.

\section{UCAPAN TERIMA KASIH}

Ucapan Terikasih kepada Semua pihak yang terlibat baik secara langsung maupun tidak dalam kegiatan Program Kemitraan masyarakat (PKM) ini. Secara umum ucapan terimakasih kapada Keuchik, BUMG, dan warga Gampong Seuneubok Baroh. Secara khusus kami sampaikan ucapan terimakasih kepada Rektor UNSAM, LPPM-PM UNSAM, dan Direktorat Riset dan Pengabdian Masyarakat (DRPM) KEMRISTEK DIKTI Tahun Anggaran 2019.

\section{DAFTAR PUSTAKA}

Irawan, H. 2017. Penerapan e-commerce berbasis web untuk meningkatkan pangsa pasar penjualan keripik di UD aduhai di Gampong Karanganyar kec langsa baro kota langsa. Seminar Nasional Teknik Industri 2017 ISSN 2338-7122.

Irwansyah, dkk. 2018. Batu bata tanpa pembakaran dari limbah industry pertanian dan material alam. Jurnal Teknik Bangunan dan Sipil Educational Building 4(2) ISSN 2477-4901. UNIMED Medan 
Yuliarman, dkk. 2004. Rancang Bangun mesin pencetak batu bata dengan systemesktrusi. Jurnal Teknik Mesin 1(1) ISSN 1829-8958. Politeknik Negeri Padang 